\title{
МЕХАНІЗМ РЕАЛІЗАЦІЇ КОНСТИТУЦІЙНОГО ПРАВА НА ДЕРЖАВНУ СЛУЖБУ В ОРГАНАХ ДЕРЖАВНОЇ ВЛАДИ УКРАЇНИ
}

Cьох K. Я.

\begin{abstract}
У науковій статті досліджено механізм реалізації конституційного права громадян на державну службу в органах державної влади в Україні. Ця тема є досить актуальною з огляду на сучасний розвиток державної служби. Започаткування у 2014-2015 роках масштабної реформи державного управління в Україні та прийняття Закону України «Про державну службу» у 2015 році стало приводом для нових досліджень утілення норм закону у практичну реалізацію громадянами України. Чітко встановлений механізм реалізації дослідженого права, закріплений на законодавчому рівні, дасть можливість громадянам України реалізувати дане їм право Конституцією України.

У статті розтлумачується визначення механізму реалізації конституційного права громадян України на державну службу. Також зроблено акцент на проведення конкурсного відбору кандидатів на вступ до органів державної влади як одного з елементів механізму реалізації права громадян України на державну службу. Проаналізовано чинне законодавство та запропоновані шляхи його вдосконалення.

Ключові слова: державна служба, державний службовець, право на державну службу, механізм реалізаціі права на державну службу, конкурсну випробування, конкурсна комісія.
\end{abstract}

В научной статье исследовано механизм реализации конституционного права граждан на государственную службу в органах государственной власти в Украине. Данная тема является весьма актуальной, учитывая современное развитие государственной службы. Начало в 2014-2015 годах масштабной реформы государственного управления в Украине и принятие Закона Украины «0 государственной службе» у 2015 году стало поводом для новых исследований воплощения норм закона в практической реализации гражданами Украины. Поскольку четко установлен механизм реализации исследованного права, закрепленный на законодательном уровне, даст возможность гражданам Украины реализовать данное им право Конституцией Украины.

B статье растолковывается определения механизма реализации конституционного права граждан Украины на государственную службу. Также сделан акцент на проведении конкурсного отбора кандидатов на вступление в органы государственной власти как одного из элементов механизма реализации права граждан Украины на государственную службу. Проанализировано действующее законодательство и предложены пути его.

Ключевые слова: государственная служба, государ ственный служащий, право на государственную службу, механизм реализации права на государственную службу, конкурсную испытания, конкурсная комиссия.

Sokh K. Ya. The mechanism of realization of the constitutional right to civil service in public authorities of Ukraine

The article is devoted to the study of the mechanism of realization of the constitutional right of citizens to civil service in

(c) Cbox К. Я., 2020 public authorities in Ukraine. This topic is quite relevant given the current development of civil service. The launch in 20142015 of a large-scale public administration reform in Ukraine and the adoption of the Law of Ukraine "On Civil Service" in 2015, was the reason for new research into the implementation of the law in practice by citizens of Ukraine. Problems of theory and practice of realization of the right to civil service by citizens of Ukraine and its legislative regulation are a constant reason for scientific interpretation and research. As the mechanism of realization of the investigated right established at the legislative level will be accurately established will give the chance to citizens of Ukraine to realize the right given to them by the Constitution of Ukraine.

The article explains the definition of the mechanism of realization of the constitutional rights of citizens of Ukraine to civil service. Which should be understood as an orderly set of subjective and objective factors that are necessary conditions for the implementation of this right, which are determined by the relevant constitutional provisions and interpreted by other regulations of Ukraine.

It is emphasized that civil service is an element of the organization of society in the state and is a link between the state and society as a whole. It is emphasized that civil service is a professional activity with clearly defined competencies and a system of rules of official duties for the performance of tasks and functions of the state. Therefore, it is extremely important that the functions of the state are performed by highly professional officials.

Emphasis is placed on the competitive selection of candidates for admission to public authorities, as one of the elements of the mechanism for exercising the right of citizens of Ukraine to civil service. The current legislation is analyzed and the ways of its improvement are suggested.

Key words: civil service, civil servant, right to civil servant, mechanism of realization of the right to civil service, competitive test, competitive commission.

Постановка проблеми та її актуальність. Конституційне право громадян України на держану службу урегульоване нормами Конституції України (ст. 38) та деталізоване в поточному законодавстві.

Конституція України у ст. 38 закріпила право громадян України на рівний доступ до державної служби. Це право має універсальний характер та потребує постійного вдосконалення національного законодавства задля його реалізації. Водночас право на державну службу не набуло абсолютного характеру, оскільки громадяни України мають відповідати чітко встановленим вимогам, які внормовані національним законодавством України. Отже, зважаючи на це право, для державної служби є певні обмеження, тому науковці все частіше звертаються до аналізу законодавства щодо реалізації цього права.

Реалізація конституційних прав громадян України на державну службу як й інших політичних прав і свобод, неможлива без забезпечення організаційно-політичної 
діяльності системи органів і посадових осіб органів державної влади, громадських організацій, підприємств, установ та організацій. Діяльність названих суб'єктів у цій сфері $\epsilon$ свідченням реальності свободи особистості, проголошеної в суспільстві, фактор утілення правових можливостей у сферу реального використання соціальних благ, користування благами свободи, котрі закріплені в Конституції України. Отже, у складі державного управління державна служба $\epsilon$ визначальним складником, від якого залежить дотримання конституційних прав та свобод громадян та результативність та ефективність розвитку країни загалом. Тому важливо визначити дієвий механізм реалізації права громадян України на державну службу, від яких залежатиме розвиток держави, та закріпити їх у національному законодавстві України.

Аналіз останніх досліджень і публікацій. Актуальність цієї теми підтверджується кількістю наукових досліджень, статей та монографій, які науковці присвятили цій темі. Серед них можна виділити таких учених, як В. Авер'янов, Н. Камінська, Б. Калиновський, В. Костюк, О Линдюк, О. Оболенський, В. Рабінович, А. Чаркіна, І. Яцкевич, та інші. Кожен із цих науковців зробив вагомий внесок у дослідження державної служби, але достатньо уваги не було приділено механізму реалізації конституційного права громадян України на державну службу.

Метою статті $\epsilon$ дослідження механізму реалізації конституційного права громадян України на державну службу в органах державної влади та оцінка сучасного стану нормативно-правового регулювання щодо реалізації цього права.

Виклад основного матеріалу. Сучасний етап розвитку державного управління в Україні спрямований на створення оптимальної структури державної служби та на забезпечення права громадян України на державну службу. Із часів незалежності нашої держави законодавці та науковці шукають шляхи для вдосконалення механізму реалізації права громадян на державну службу. Адже державна служба є невід'ємною від розвитку держави та відображає стан державності, вдосконалюється та структурується разом із розвитком держави.

Під механізмом реалізації конституційного права громадян України на державну службу варто розуміти впорядковану сукупність суб'єктивних й об'єктивних чинників, котрі виступають необхідними умовами втілення благ, які визначені відповідними конституційними положеннями, приписами інших нормативно-правових актів, у практику як індивідуальної професійної життєдіяльності конкретної посадової особи органу державної влади, так і функціонування інститутів державної служби [1, с. 195].

Останні декілька років державна служба перебуває в умовах змін та вдосконалення. Оскільки із 2014 року Україна вступила на шлях до Європейського Союзу та взяла на себе зобов'язання адаптації національного законодавства України до європейських стандартів. Як наслідок, у 2015 році було прийнято новий Закон України «Про державну службу» від 10.12.2015, який відповідає принципам демократії, гуманізму та дотримання прав і свобод людини, а також розтлумачує конституційне право громадян України на державну службу та умови його реалізації. Однак під час реалізації цього права громадяни стикаються із проблемами, які не врегульо- вані законодавством України та призводить до порушення конституційного права про державну службу.

Відповідно до Закон України «Про державну службу» державна служба - це публічна, професійна, політично неупереджена діяльність із практичного виконання завдань і функцій держави, зокрема, щодо:

1) аналізу політики на державному загальному, галузевому й регіональному рівнях та підготовки пропозицій щодо іï формування, зокрема розроблення та проведення експертизи проєктів програм, концепцій, стратегій, законів та інших нормативно-правових актів, проєктів міжнародних договорів;

2) забезпечення реалізації державної політики, виконання загальнодержавних, галузевих і регіональних програм, виконання законів та інших нормативно-правових актів;

3) забезпечення надання доступних і якісних адміністративних послуг;

4) здійснення державного нагляду та контролю за дотриманням законодавства;

5) управління державними та фінансовими ресурсами, майном та контролю за їх виконанням;

6) управлінням персоналом державних органів;

7) реалізації інших повноважень державного органу, визначених законодавством [4].

Цим визначенням законодавець показав важливість державної служби загалом. Перед державними службовцями стоять надважливі завдання, які визначені Конституцією України та законами України. Суть їх полягає у збереженні суверенітету незалежності розвитку України як демократичної, соціальної, правової держави, де людина, іiї життя і здоров'я, честь і гідність, недоторканність і безпека визначаються найвищими соціальними цінностями, а права та свободи людини і громадянина та їх гарантії визнаються змістом і спрямованістю діяльності держави.

Державний службовець - це громадянин України, котрий займає посаду державної служби в органі державної влади, іншому державному органі, його апараті (секретаріаті), одержує заробітну плату за кошт державного бюджету та здійснює встановлені для цієї посади повноваження, безпосередньо пов'язані з виконанням завдань і функцій такого державного органу, а також дотримується принципів державної служби [4].

Відповідно до ст. 38 Конституції України «Громадяни користуються рівним правом доступу до державної служби, а також до служби в органах місцевого самоврядування» [2].

Отже, аналізуючи чинне законодавство України, можна зробити висновки, що всі громадяни України мають право займати посади державної служби в органах державної влади та виконувати завдання та функції держави. Про це зазначає Конституція України та розтлумачує Закон України «Про державну службу», але цього недостатньо щоб реалізувати конституційне право на державну службу. Громадяни України, які виявляють бажання вступити на державну службу, повинні відповідати певним установленим вимогам та критеріям, котрі висуваються до претендентів на вакантні посади державної служби всіх категорій - «А», «Б», «В». Частина перша ст. 19 цього Закону встановлює, що правом на державну службу наділені особи, які:

1) а) мають громадянство України;

2) б) досягли повноліття; 
3) в) вільно володіють державною мовою;

4) г) мають відповідний посаді державної служби ступінь вищої освіти [4]. Але, відповідаючи всі цим вимогам, громадянин України не завжди може реалізувати своє право на державну службу.

Вищевказаним законом зазначені і критерії, якими законодавець також унормовує умови, які обмежують право громадян на доступ до державної служби, що відповідає ч. 1 ст. 64 Конституції України, котра не містить відповідне право в переліку таких, які не можуть обмежуватись.

До таких умов належать:

1) досягнення громадянином 65-річного віку;

2) визнання особи в судовому порядку недієздатною або такою, дієздатність якої $\epsilon$ обмеженою;

3) має непогашену й не зняту судимість за умисний злочин;

4) позбавлена судом права виконувати функції державної влади й місцевого самоврядування;

5) піддавалась протягом трьох років адміністративному стягненню за корупційне правопорушення;

6) має громадянство іншої держави (множинне громадянство);

7) не пройшла спецперевірку чи не дала згоду на іï перевірку;

8) підпадає під люстрацію [4].

Отже, зважаючи на це, не всі громадяни можуть реалізувати конституційне право на державну службу.

Для ефективного та якісного виконання завдань i функцій держави, побудови професійної, престижної, орієнтованої на потреби громадян державної служби необхідні, передусім, кваліфіковані кадри. Тому Законом України «Про державну службу» встановлено умови вступу на державну службу. Відповідно до ч. 1 ст. 19 Законом України «Про державну службу» зазначено таке: «Право на державну службу мають повнолітні громадяни України, які вільно володіють державною мовою та яким присвоєно ступінь вищої освіти», ч. 1 ст. 21 «Вступ на державну службу здійснюється шляхом призначення громадянина України на посаду державної служби за результатами конкурсу», ч. 3. ст.31 «Рішення про призначення на посаду державної служби приймається суб'єктом призначення після проведення співбесіди» [4]. Отже, для реалізації права на державну службу, відповідно до вищевказаного закону, потрібно бути громадянином України, володіти державною мовою, мати вищу освіти та пройти конкурсні випробування та співбесіду. 3 огляду на норми Закону проблем не повинно виникати, але на практиці норми закону не реалізуються повною мірою.

Ураховуючи досвід країн Європи, законодавець України чітко прописав вимоги щодо проведення конкурсу на заміщення вакантних посад на державну службу з метою відбору якісно підготовлених та професійних службовців, які ефективно виконуватимуть функції держави. Процедуру проведення конкурсу затверджено Законом України «Про державну службу» та Порядком проведення конкурсу на зайняття посад державної служби, затвердженим постановою КМУ від 25.03.2016 р. № 246 (зі змінами) [4, 5].

Одним із нових та прозорих етапів для нашої держави $€$ створення Єдиного порталу вакансій державної служби Національного агентства України з питань державної служби, на якому відображаються всі вакантні посади на державну службу у всій Україні і кожен громадянин України може у вільному доступі переглянути іх та обрати собі бажану вакансію. Також на цьому порталі законодавець передбачив подання в електронному вигляді документів, які необхідні для участі в конкурсі. Це дійсно $€$ новим етапом прозорості та зручності, оскільки вакантні посади в органи державної влади не можуть бути заміщені без офіційного оголошення конкурсу на відповідному порталі. Отже, керівником органу державної влади обов'язково приймається рішення про оголошення конкурсу, після чого видається наказ про оголошення конкурсу, в якому вказуються умови, дата та час його проведення, та розміщуються на Єдиному порталі вакансій державної служби.

Кожен громадянин України, котрий виявив бажання реалізувати право на державну службу, має право обрати собі вакансію на порталі та подати необхідну інформацію, яка дає право на участь у конкурсі. Відповідно до Порядку проведення конкурсу на зайняття посад державної служби [5], до такої інформації належить:

заява про участь у конкурсі із зазначенням основних мотивів щодо зайняття посади за формою, згідно з додатком 2 Порядку;

резюме за формою, згідно з додатком 2-1 Порядку, в котрому зазначаються паспортні дані, відомості про вищу освіту, підтвердження рівня вільного володіння державною мовою, стаж роботи, стаж державної служби (за наявності), досвід роботи на відповідних посадах згідно з вимогами, визначеними в умовах проведення конкурсу;

заяву, в якій повідомляють, що до них не застосовуються заборони, визначені ч. 3 або ч. 4 ст. 1 Закону України «Про очищення влади» [8], та надають згоду на проходження перевірки й оприлюднення відомостей щодо них, відповідно до зазначеного Закону.

Також за бажанням можна подавати й додаткову інформацію, зокрема щодо попередніх результатів тестування, досвіду роботи, компетентностей репутації (характеристики, рекомендації, наукові публікації тощо). На електронні документи, які подаються для участі в конкурсі, обов'язково накладається кваліфікований електронний підпис кандидата. Для цього потрібно створити власний профіль користувача та заповнити необхідну інформацію. Про результати розгляду поданої інформації служба управління персоналом державного органу повідомляє кандидата одним із доступних способів, обраних ним, протягом трьох днів із дня іï надходження.

У разі, якщо інформація, надана кандидатом на посаду, відповідає встановленим умовам, конкурсант допускається до наступного, досить важливого етапу конкурсу - тестування на знання Конституції України, законодавства про державну службу, антикорупційного та іншого законодавства. Перелік тестових питань із варіантами відповідей затверджується Національним агентством України з питань державної служби та оприлюднюються на його офіційному веб-сайті.

Результати тестування залежать від належного рівня підготовки кандидата на державну службу. Важливим моментом на цьому етапі $\epsilon$ те, що тестування проходить в електронному вигляді за допомогою технічних засобів і результат проходження висвітлюється відразу. Це свідчить про прозорість відбору кандидатів, 
оскільки перемагає кандидат, який набрав найбільшу кількість балів, а отже, він має найвищий рівень підготовки. Якщо кандидат претендує на посади категорії «Б», можуть бути запропоновані ситуаційні завдання, за результатами яких оцінюється рівень професійної компетентності кандидата, відповідно до посадових обов'язків. Результати проходження конкурсу оголошує Комісія у складі не менше 5-ти осіб, яка створена органом призначення.

У разі проходження тестування та розв'язання ситуаційних завдань (для категорії «Б») кандидати допускаються до співбесіди, під час якої кожен член конкурсної комісії оцінює знання, вміння, компетенції, необхідні особистісні якості конкурсантів. Шляхом додавання середніх балів, набраних конкурсантами під час проходження всіх етапів конкурсу, визначається загальна кількість балів кожного та формується загальний рейтинг кандидатів. П'ять кандидатів із найбільшою кількістю балів, відповідно до загального рейтингу, запрошуються до завершального етапу конкурсного відбору - співбесіди, яку проводить керівник державної служби, та за ії результатами приймає рішення про переможця конкурсу або про його відсутність.

Проаналізувавши чинне законодавство щодо реалізації права громадян України на державну службу, можна зробити висновок, що це досить кропітка робота, яка до снаги лише громадянам України котрі поставили собі за мету вступити на службу до органів державної влади.

Але, як показує досвід, недостатньо відповідати вимогам, які поставив орган державної влади, та пройти конкурсні випробування. На жаль, громадяни України стикаються 3 такою проблемою, як корупційні зв'язки, що виникають під час конкурсного випробування та співбесіди.

Відповідно до ч. 1 ст. 27 Закону України «Про державну службу» «конкурс на зайняття вакантних посад державної служби категорії «Б» в усіх інших випадках та категорії «В» проводить конкурсна комісія, утворена керівником державної служби або суб'єктом призначення» [4]. Тобто керівник органу державної влади оголосив конкурс на заміщення вакантної посади, створює наказом конкурсну комісію із представників підконтрольного йому органу. Відповідно до ч. 2 ст. 27 цього закону «до складу конкурсної комісії можуть залучатись представники громадських об'єднань, котрі діють згідно із Законом України «Про громадські об'єднання» $[3,4]$, але можуть і не долучатись. На мою думку, конкурсна комісія має бути створена із представників, незалежних від органу державної влади, який оголосив про вакантні посади, це дасть можливість уникнути корупційних зав'язків та обрати найбільш кваліфікованих державних службовців. Тому пропоную внести зміни до чинного законодавства, а саме у ст. 27 Закону України «Про державну службу», та зазначити про заборону залучення представників органу державної влади, який оголосив конкурс на заміщення вакантної посади бути членами конкурсної комісії. Такі зміни дадуть можливість проводити конкурс прозоріше та уникаючи незаконних дій, тим самим не порушуючи конституційне право громадян України.

Висновки. Запорукою стабільності та розвитку держави $\epsilon$ ефективна система органів державної влади, котра функціонує за допомогою висококваліфікованих державних службовців. Для досягнення такого результату потрібно створити дієвий механізм, який дає можливість кожному громадянину України реалізувати право на державну службу без перешкод. Таким механізмом має бути, перш за все, чіткі норми Закону, що не дають приводу для порушення цього права. Пропонуємо внести зміни до нормативно-правових актів, де зазначити таке:

1) під час проходження конкурсного випробування унеможливити контакт кандидатів із представниками Комісії до проведення конкурсу. Список членів комісіє має бути таємним як для кандидата на вакантну посаду, так і для органу державної влади, котрий оголосив конкурс;

2) під час співбесіди кандидатів мають відбирати лише представники Конкурсної комісії, без представників органу державної влади, щоб уникнути корупційних зв'язків;

3) заборонити посадовим особам органу державної влади, який оголосив конкурс, бути членами конкурсної комісії. Ці зміни дадуть можливість відібрати висококваліфікованих фахівців на посади в органи державної влади.

\section{Література}

1. Конституція України. Відомості ВРУ. 1996. № 30. Ст. 141. URL: http://www.zakon.rada.gov.ua/.

2. Камінська Н., Сьох К. Забезпечення прав громадян на державну службу та службу в органах місцевого самоврядування в умовах децентралізації влади та євроінтеграції : монографія. Київ, 2018. 257 с.

3. Про громадські об'єднання : Закон України 22.03.2012. URL: https://zakon.rada.gov.ua/laws/show/4572-17.

4. Про державну службу: Закон України від 10.12.2015 p. URL: http://zakon3.rada.gov.ua/laws/show/889-19.

5. Порядок проведення конкурсу на зайняття посад державної служби : Постанова КмУ від 25.03.2016 p. № 246. URL: https://zakon.rada.gov.ua/laws/ show $/ 246-2016-\% \mathrm{D} 0 \% \mathrm{BF}$.

6. Сьох К. Реалізація конституційного права на державну службу в умовах сьогодення. Верховенство права як гарантія конституційного ладу (науково-практичний круглий стіл 5 грудня 2019 НАВС). Київ. 2020. С. 159-161.

7. Чаркіна А. Адаптація державної служби України до вимог ЄС: нормативно-правовий вимір : дис. ... кан. юрид. наук. Дніпро. 2018. 225 с.

8. Про очищення влади : Закон України від 16.09.2014 URL: https://zakon.rada.gov.ua/laws/show/1682.

Сьoх К. Я., кандидат юридичних наук, старший викладач кафедри конститучійного права та прав людини Національної академії внутрішніх справ 